Merve Baş, Melisa Aksu, Hüseyin Ünübol ve Gökben Hızlı Sayar. "Akademisyenlerde İş doyumunun Algılanan Sosyal Destekle İlişkisinin İncelenmesi," Üsküdar Üniversitesi Sosyal Bilimler Dergisi, sayı: 9,

(Kasım 2019): 345-375, http://doi.org/10.32739/uskudarsbd.5.9.62

\title{
Akademisyenlerde İş Doyumunun Algılanan Sosyal Destekle İlişkisinin İncelenmesi
}

\section{Investigation of the Relationship Between Job Satisfaction and Percepted Social Support in Academicians}

\section{Merve BAŞ ${ }^{(*)}$, Melisa AKSU ${ }^{(* *)}$, Hüseyin ÜNÜBOL ${ }^{(* *)}$, Gökben HIZLI SAYAR ${ }^{(* * *)}$}

\section{$\ddot{0 z}$}

$\mathrm{Bu}$ araştırmada akademisyenlerdeki iş doyumunun, algılanan sosyal destekle ilişkisinin incelenmesi amaçlanmıştır. Ayrıca çalı̧̧ma içerisinde iş doyumu, alğlanan sosyal destek ve sosyodemografik değişkenler arasındaki ilişki de incelenmiştir. Araştırmaya Üsküdar Üniversitesi akademisyenlerinden 84 kişi katılmıştır. Katılımcılara Sosyodemografik Veri Formu, Minnesota İs Doyumu Ölçeği ve Çok

Üsküdar Üniversitesi Sosyal Bilimler Dergisi, 2019;

sayl: 9 , $347-377$

\section{Özgün Araștırma Makalesi (Original Research Article)}

Geliş Tarihi: 09.08.2019 Kabul Tarihi: 27.09.2019

Üsküdar Üniversitesi Girişimsel Olmayan Araştırmalar Etik Kurulunun 03/09/2018 tarihinde yapılan 09 no'lu toplantısında B.08.6.YÖK.2.ÜS.0.05.0.06/2018/808 numarayla araştırma desen ve içeriğinin etik açıdan uygun olduğuna karar verilmiştir.

(*) Üsküdar Üniversitesi, Klinik Psikoloji Yüksek Lisans Programı öğrencisi, İstanbul, mervebas14@gmail.com

ORCID ID:https: / / orcid.org/0000-0002-3870-9029

${ }^{(*)}$ Üsküdar Üniversitesi, İnsan ve Toplum Bilimleri Fakültesi, Psikoloji Bölümü öğrencisi, İstanbul, melisaaksu2@gmail.com

ORCID ID:https://orcid.org/0000-0002-8707-0815

${ }^{(* *)}$ Dr. Öğr. Üyesi, Üsküdar Üniversitesi Sosyal Bilimler Enstitüsü, İstanbul, huseyin.unubol@ uskudar.edu.tr

ORCID ID:https://orcid.org/0000-0003-4404-6062

${ }^{(* * *)}$ Doç.Dr., Üsküdar Üniversitesi Sosyal Bilimler Enstitüsü, İstanbul, gokben.hizlisayar@uskudar. edu.tr

ORCID ID:https://orcid.org/0000-0002-2514-5682 


\section{Merve BAŞ, Melisa AKSU, Hüseyin ÜNÜBOL ve Gökben HIZLI SAYAR}

Boyutlu Algılanan Sosyal Destek Ölçeği uygulanmıştır. Verilerin analizi için Tek Yönlü Varyans Analizi, Bağımsız Gruplarda T-Testi ve Pearson Korelasyon Analizi kullanılmıştır. Araştırmanin sonucuna göre Minnesota İş Doyumu Ölçeğinin (MİDÖ) Dışsal Doyumu ile Çok Boyutlu Algılanan Sosyal Destek Ölçeğinin (ÇBASDÖ) diğer önemli kişi destek alt ölçeği arasında istatistiksel olarak anlamlı ve pozitif yönde bir ilişki saptanırken MİDÖ ve ÇBASDÖ arasında diğer alt ölçeklere bakıldığında herhangi bir ilişkiye rastlanmamıştır. Araştırmada kullanılan ölçeklerin dişsal doyum ve diğer önemli kişi destek alt boyutları arasında bir ilişki olduğu sonucu ortaya çıkmıştır. Bu bilgilere ek olarak yaş, unvan, ailede akademisyen olma durumu ve haftada verilen ders saatinin iş doyumu ve algilanan sosyal destek düzeylerinde bir değişikliğe sebep olmadiğı sonucuna ulaşıllıken hem cinsiyet hem medeni durumun iş doyumu ve algilanan sosyal destek düzeyleri üzerinde etkili olduğu sonucuna ulaşılmıştır.

Üsküdar

University

Journal of Social

Sciences, 2019;

issue: 9 ,

$347-377$

Anahtar Kelimeler: İş Doyumu, Alğlanan Sosyal Destek, Minnesota İş Doyumu Ölçeği, Çok Boyutlu Algılanan Sosyal Destek Ölçeği, Destek Sistemleri.

\section{Abstract}

The objective of this study was to investigate the relationship between job satisfaction and percepted social support among the academicians. Eighty-four academicians who worked in Uskudar University participated in the study. Sociodemographic Data Form, Minnesota Satisfaction Questionnaire and Multidimensional Scale of Perceived Social Support were administered to participants. One-way analysis of variance, independent samples t-test and Pearson correlation analysis were used for the analysis of the data. As a result of the study, although there were statistically significant and positive relationship between the Minnesota Satisfaction Questionnaire-Extrinsic Satisfaction and Multidimensional Perceived Social Support subscales, neverthless no relationship between any other subscales was found. It was found that there was a relationship between external satisfaction and other important person support subscales of the scales used in the study. In addition to this information, it was concluded that factors such as age, title, academicians among the family members and lecture hours per week did not cause any change in job satisfaction and perceived social support levels, while both gender and marital status had an effect on job satisfaction and perceived social support levels.

Keywords: Job Satisfaction, Perceived Social Support, Minnesota Satisfaction Questionnaire-Extrinsic Satisfaction, Multidimensional Perceived Social Support, Support Systems. 
Akademisyenlerde İş Doyumunun Algılanan Sosyal Destekle İlişkisi

\section{Giriş}

Geçmişten günümüze gelinceye kadar "iş” insan yaşamında her zaman var olmuştur. Günümüzde bireylerin ihtiyaçlarına yönelik farklı iş kolları vardır ve hızla gelişen toplumda teknolojinin de artmasıyla yeni iş kolları da oluşmaya devam etmektedir. "İşs, örgütsel ortamda belirli bir zaman diliminde gerçekleşen, beraberinde kimi ilişkileri getiren ve ücret karşılığı girişilen mal ve hizmet üretme çabasıdır.” Önceki dönemlerden günümüze ulaşıncaya kadar toplumun ihtiyaçları iş alanlarını belirlemiştir. Bazı alanlara olan ihtiyaç ise tarih boyunca hep önemli bir yer edinmiştir. Eğitim alanı bunlardan bir tanesidir. Bir toplumun gelişebilmesi için o toplum içerisindeki bireylerin iyi bir eğitim alması büyük önem taşır. Bu açıdan bakıldığında toplumda eğitim veren kuruluşların büyük bir önemi vardır. Şüphesiz ki bireyleri iş hayatına hazırlayan, üniversitelerde eğitim veren akademik personele de bu konuda büyük bir rol düşmektedir. Akademisyenlerin de daha iyi bireyler yetiştirebilmesi için öncelikle yaptıkları işten kendilerinin doyum almaları gerekmektedir. Kişinin yaptığı işten doyum alması onun yaşam doyumu ve üretkenliği açısından da önem taşımaktadır. ${ }^{2} \mathrm{Bu}$ araştırmanın amacı akademisyenlerde iş doyumu ile algılanan sosyal desteğin ilişkisinin saptanmasıdır.

\section{İş Doyumu}

Günümüzde çalışan bireyler vakitlerinin büyük bir kısmını iş için harcarlar. Zamanlarının büyük bir kısmını burada geçiren bireylerin

\footnotetext{
${ }^{1}$ Nuran A. Aşık, “Çalışanlarda İş Doyumunu Etkileyen Bireysel ve Örgütsel Faktörler ile Sonuçlarına İlişkin Kavramsal Bir Değerlendirme,” Türk İdare Dergisi, sayı: 467 (2010): 31-51.

${ }^{2}$ Rufat Karlıdağ, Süheyla Ünal, ve Salim Yoloğlu, "Hekimlerde Tükenmişlik ve İş Doyumu Düzeylerinin Yaşam Doyumu Düzeyleri ile İlişkisi,” Klinik Psikiyatri, sayı: 4 (2001): 113-118.
} 


\section{Merve BAŞ, Melisa AKSU, Hüseyin ÜNÜBOL ve Gökben HIZLI SAYAR}

işlerinden daha fazla keyif alabilmeleri için, yaptıkları işin beklentilerini karşılaması anlamlıdır.. Bireylerin çalıştıkları işten aldıkları doyum, yaşam doyumlarına da etki edecektir. Yapılan 10 yıllık bir meta-analiz çalışmasının sonucunda iş doyumu ve yaşam doyumu arasında anlamlı bir ilişki olduğu görülmüştür. ${ }^{3}$ Ayrıca bireylerin işlerinden aldıkları doyum arttıkça iş verimliliğinin de artması beklenen bir durumdur. İş doyumunun yüksek olması örgüt tarafından beklenen yüksek verimlilik, devamsızlığın azalması ve işe bağlılığın artması gibi sonuçları beraberinde getirecektir. İyi bir performans örgütlerin çalışanlarından bekledikleri en önemli beklentiler arasında yer alır. İş doyumu yüksek olan bireyler verimlilikle beraber çalıştıkları kurumlara başarıyı da getirecektir. Dolayısıyla örgütler açısından bakıldığında iş doyumu kavramının önemi artmaktadır. Bireyin işinden alacağı doyum birçok farklı duruma göre değişebilir. Her bireyin işinden alacağı doyumu farklı değişkenler belirleyebilir. Bunlar arasında maaş, iş çevresi, yaş, medeni durum vb. yer alabilir. İş doyumu kavramına ilk ne zaman değinildiğine bakılacak olursa bunun 1920'li yıllarda başladığı ancak konunun öneminin 1940’lı yıllarda tam olarak anlaşıldığı belirtilmiştir. ${ }^{4}$ Literatür taraması yapıldığında da iş doyumu alanında yapılan pek çok araştırma olduğu görülmektedir. Ayrıca iş doyumu kavramı çalışma psikoloji alanında da yaygın bir şekilde kullanılan bir kavramdır. Bireyleri işe karşı neyin motive ettiği veya neyin motivasyonlarını düşürdügünü anlamak toplum içerisinde daha üretken bireylerin olmasına da katkı sağlayacaktır. İş doyumu da bireylerin işi ve iş yerleriyle ilgili genel duygu ve düşünceleri hakkında fikir verebilecek önemli bir değişkendir. İş doyumuna dair tanımlamalara

\footnotetext{
${ }^{3}$ Ahmet A. Dikmen, “İş Doyumu ve Yaşam Doyumu İlişkisi,”Ankara Üniversitesi SBF Dergisi, sayı: 50 (1995): 115-140.

${ }^{4}$ Ayşen Temel Eğinli, "Çalışanlarda İş Doyumu: Kamu ve Özel Sektör Çalışanlarının İş Doyumuna Yönelik Bir Araştırma,” Atatürk Üniversitesi İktisadi ve İdari Bilimler Dergisi 3, say1: 23 (2009): 35-52.
} 
Akademisyenlerde İş Doyumunun Algılanan Sosyal Destekle İlişkisi

bakıldığında tanımların farklılık gösterdiği söylenebilir. Farklı kişilerin iş doyumuna dair farklı tanımları mevcuttur. "İş doyumu, işin özellikleriyle bireylerin kendinde bulduğu özelliklerin uyum içinde olması şeklinde tanımlanabilir. İşgören, kendi standartları ile bu standartların hangisinin ne ölçüde karşılandığını karşılaştırdığında oluşan farklılıklar iş doyumunu belirlemektedir."5 Araştırmacılar, iş doyumunu çalışanların işlerinden duydukları memnuniyeti ya da memnuniyetsizliği ifade eden iki uçlu bir kavram olarak tanımlamışlardır. ${ }^{6}$ Hulin ve Judge iş doyumunun kognitif, duygusal ve davranışsal unsurları da kapsayan, kişinin işine karşı olan çok boyutlu psikolojik cevaplarını içerdiğini belirtmiştir. ${ }^{7}$ Spector iş doyumunun üç önemli özelliğini listelemiştir. İlk olarak, örgütler insani değerlere göre yönetilmelidir;ikinci olarak çalışanların iş doyumu düzeylerine bağlı olarak davranışları örgütlerin işlerindeki aktiviteleri ve işleyişi etkileyecektir; üçüncü olarak ise iş doyumu örgütsel faaliyetlerin göstergesi olabilir, şeklinde sıralamıştır. Aynı zamanda iş doyumunu açıklayan pek çok farklı kuram vardır. Bu kuramların birçoğu iş doyumu ve güdülenme arasındaki ilişkiyi temel almaktadır.

\section{Akademisyenlik Açısından İş Doyumunun Önemi}

Eğitim toplumlar için her dönemde büyük bir önem taşımıştır. Günümüzde de toplumların gelişebilmesi ve daha ileri seviyelere ulaşabilmesi açısından bu konu hala büyük bir önem taşımaktadır. $\mathrm{Bu}$ açıdan bakıldığında toplum içerisindeki bireylerin daha iyi yerlere gelmesini sağlayan eğitim kurumları da büyük bir öneme sahiptir.

\footnotetext{
${ }^{5}$ Yasemin Akman, Filiz Bilge ve Hülya Kelecioğlu, "Öğretim Elemanlarının İş Doyumlarının İncelenmesi,” Hacettepe Üniversitesi Eğitim Fakültesi Dergisi, sayı: 32 (2007): 32-41.

${ }^{6}$ Meral Öztürk ve Ercan Şahbudak, “Akademisyenlikte İş Doyumu," Uluslararası Sosyal Araştırma Dergisi 40, sayı: 8 (2015): 494-501.

${ }^{7}$ Ashak P. Singh, Amish Singh ve Nitu Singhi, "Organizational Role Stress and Social Support as Predictors of Job Satisfaction Among Managerial Personnel," Journal of Psychosocial Research 1, say1: 10 (2015): 1-10.
} 


\section{Merve BAŞ, Melisa AKSU, Hüseyin ÜNÜBOL ve Gökben HIZLI SAYAR}

Özellikle bireyleri iş hayatına hazırlayan üniversitelerin toplum içindeki yeri tartışılamaz bir önem taşımaktadır. Dolayısıyla bu kurumlarda eğitim vermekte olan akademik personele de bu konuda büyük bir sorumluluk düşmektedir. Sergiovanni ve Starratt öğretim elemanlarının iş doyumları ile öğrencilerin akademik başarıları arasındaki ilişkiye dikkat çekerek, akademisyenlerin işlerinden doyum sağlamalarının önemini vurgulamaktadır. Krishna ve Nandan akademisyenlerdeki iş doyumunun hem öğrenci hem kurum için önemli bir konu olduğunu belirtmişlerdir. ${ }^{8}$ Toplum içerisinde yüksek iş doyumuna sahip akademisyenlere sahip olmak büyük önem taşırken bu alanda yapılan çalışmaların sayısı da gün geçtikçe artmaktadır. Akademisyenlerin iş doyumuna hangi faktörlerin

Üsküdar University Journal of Social Sciences, 2019; issue: 9 , $347-377$ etki ettiğiyle ilgili literatür taraması yapıldığında ise farklı sonuçlara rastlamak mümkündür.

\section{İş Doyumuyla İlgili Kuramlar}

İş doyumuyla ilgili kuramlara baktığımızda en çok göze çarpan Herzberg'in Çift Faktör Teorisi ve Maslow'un Gereksinim Hiyerarşisi kuramıdır. Ancak bu konuyla ilgili daha fazla kuram mevcuttur. Literatürde iş doyumunu açıllayan teorilerin genellikle Kapsam ve Süreç teorileri olarak iki grupta sınıflandırıldığı görülmektedir.

Maslow'un Gereksinim Hiyerarşisi Kuramının temelinde kişinin temel ihtiyaçları vardır ve bunlar belli bir hiyerarşi içerisindedir. Kişi bir önceki basamakta bulanan ihtiyacını gidermeden bir sonraki ihtiyacının olduğu basamağa geçmez. Maslow'un kuramına göre kişinin gerçekleştirmesi gereken 5 temel ihtiyaç vardır. Bunlar en temelden başlamak üzere sırasıyla fizyolojik ihtiyaçlar, güvenlik ihtiyacı, ait olma ve sevgi ihtiyacı, statü ve saygınlık ihtiyacı ve kendini gerçekleştirmedir.9 Maslow'un gereksinim hiyerarşisi bireylerin neden çeşitli özverilerde bulunarak başka bireylerin

\footnotetext{
${ }^{8}$ Siva Rama Krishna ve Raja Nandan, "Determinants of Job Satisfaction of Faculty in Higher Education,” The Indian Journal of Industrial Relations 1, say1: 49 (2013): 132-147.
} 
Akademisyenlerde İ̧̧ Doyumunun Algılanan Sosyal Destekle İlişkisi

düşünce ve emirleri doğrultusunda örgütlerde çalışmayı kabul ettikleri konusuna açılılı getirmeye çalışır. Bireylerin fizyolojik gereksinimlerini karşılamak üzere bir işe gereksinim duydukları, herhangi bir nedenle işsiz kaldıkları ya da haksızlığa uğradıkları durumlar için sigortalı, sendikalı olmak, gelecek için tasarrufta bulunmak gibi birtakım önlemleri ile güvenlik gereksinimlerini karşıladıklarını belirtir. Ayrıca insanların sosyal varlıklar oldukları için ait olma gereksinimleri nedeniyle anlaşabilecekleri iş grupları içinde çalışıp, kulüp, sendika ve dernekler kurdukları, saygınlık gereksinimlerini karşılamak üzere diğer insanlara hizmet vererek onların takdirini kazandıkları, bu şekilde kendilerine güvenlerin geliştiği ve topluluk içinde bir mevki sahibi olduklarını vurgular. ${ }^{9}$

McClelland'ın modeli başarı ihtiyacına ve güce odaklanır. McClelland, Maslow'un teorisindeki hiyerarşik sıralama fikrini kabul etmemiştir. Başarma, ilişki/bağlılık, güç ve bağımsızlık gibi kavramları içeren ihtiyaçları tanımlamıştır. ${ }^{10}$ Başarma ihtiyacı kişinin başarıya verdiği önem ve değer boyutuyken güç ihtiyacı başkalarını etkileme, prestij oluşturma ve bunu koruma ihtiyacıdır. Bağlılık ihtiyacı da başka kişiler ile ilişki kurma, gruba girme ve sosyal ilişkiler geliştirme olarak ifade edilebilir.

Bu konuyla ilişkili olarak dikkat çeken diğer önemli kuramlardan biri de Herzberg'in Çift Faktör Kuramı'dır. Herzberg'in kuramında iş doyumuyla ilgili faktörler iki gruba ayrılmıştır. Bunlar güdüleyici etmenler ve hijyenik etmenler başlıkları altında toplanmaktadır. Herzberg'e göre tatmine ve tatminsizliğe yol açan etmenler birbirinden farklıdır. Tatmin olma duygusu, motivatör (güdüleyici) faktörler ile ilişkiliyken, tatminsizlik

\footnotetext{
${ }^{9}$ Özlem Sun, "İş Doyumu Üzerine Bir Araştırma: Türkiye Cumhuriyeti Merkez Bankası Banknot Matbaası Genel Müdürlüğü,” (Uzman Yeterlilik Tezi, 2002).

${ }^{10}$ Richard T. Mowday, Debra L. Shapiro ve Richard M. Steers, "Introduction to Special Topic Forum: The Future of Work Motivation Theory," Academy of Management Review 3, say1: 29 (2004): 379-387, http://dx.doi.org/10.2307/20159049
}

Üsküdar Üniversitesi Sosyal Bilimler Dergisi, 2019; sayl: 9 , $347-377$ 


\section{Merve BAŞ, Melisa AKSU, Hüseyin ÜNÜBOL ve Gökben HIZLI SAYAR}

duygusu hijyen faktörleriyle ilişkilidir. ${ }^{11}$ Bu durumu açıklamak gerekirse Akman vd. güdüleyici faktörlerin olması durumunda performansın artacağını ve bunun doğrudan işin kendisinden alınan doyumla ilgili olduğunu belirtirken, hijyenik etmenlerin işin ortamı ve koşullarıyla ilgili olduğunu ve hijyen etmenlerinin olmaması durumunun doyumsuzluğa yol açacağını belirtmişlerdir. Ancak Herzberg' in kuramından bahsederken burada değinilmesi gereken bir nokta daha vardır. Herzberg'e göre iş doyumunu belirleyen iki temel faktör vardır. Bunlardan başarı, takdir gibi unsurlar (güdüleyici etmenler) iş doyumuna yol açarken bunların yokluğunda iş doyumsuzluğu ortaya çıkmamaktadır. Çalışma koşullarının

Üsküdar University Journal of Social Sciences, 2019; issue: 9 , $347-377$ iyi olmaması, düşük ücret (hijyenik etmenler) gibi olumsuzluklar iş doyumsuzluğuna sebep olurken bunların düzeltilmesi de iş doyumunun ortaya çıkmasına neden olmaz. Onaran bu durumu güdüleyici etmenlerin yalnız doyuma yol açması, hijyen etmenlerin de yalnız doyumsuzluğa yol açması şeklinde açıklamıştır. ${ }^{12}$ İş yaparken alınan doyum, işteki başarı, tanınma, takdir edilme, ilerleme ve gelişme olanakları güdüleyici etmenler olarak sıralanabilirken çalışma koşulları, işletme politikaları, süpervizyon, kişilerarası ilişkiler hijyenik etmenler olarak sıralanabilmektedir.

Adams'ın eşitlik teorisi temelde bireylerin eşitsizlik hissetmesi olarak özetlenebilir. Adams'ın teorisi iş yerindeki eksik ya da fazla ödüllendirmelerin davranışlar üzerinde etkisi olduğunu belirtir. Eğer çalışanlar iki sosyal grup veya birey arasında eşitsizlik olduğunu

\footnotetext{
${ }^{11}$ Azize Ergeneli ve Mehmet Eryiğit, “Öğretim Elemanlarının İş Tatmini: Ankara’da Devlet ve Özel Üniversite Karşılaştırması,” H. Ü. İktisadi ve İdari Bilimler Fakültesi Dergisi 2, sayı: 19 (2001): 159-178.

${ }^{12}$ Oğuz Onaran, Çalışma Yaşamında Güdülenme Kuramları (Ankara Üniversitesi Siyasal Bilgiler Fakültesi Yayınları, 1985).
} 
Akademisyenlerde İş Doyumunun Algılanan Sosyal Destekle İlişkisi

düşünürse, girdi ve çıktıların eşit olmamasından dolayı çalışanın stresli ve memnuniyetsiz olması muhtemeldir. ${ }^{13}$

Alderfer Varoluş, İlgililik ve Büyüme Teorisi’nde (ERG Kuramı) Maslow'un teorisinde yer alan 5 temel gereksinim yerine 3 gereksinim sunmuştur. ${ }^{14}$ Bunlar varoluş, ilgililik ve büyümedir. Varoluş gereksinimlerine örgütsel açıdan bakıldığında ücret ve çalışma koşulları varoluş gereksinimleridir. İlgililik gereksinimi bireylerin karşılıklı bir duygu ve düşünce paylaşımını içeren iletişim gereksinimleridir. Kabul, onay, anlayış ve etki; ilgililik sürecinin unsurlarıdır. Kendini geliştirme, yaratıcı ve verimli olma, büyüme gereksinimleri arasındadır. Bireylerin bu gereksinimlerinden doyum sağlaması, becerilerini kullanmaları ve yeni beceriler geliştirmesiyle ilişkilidir. Kişinin içinde bulunduğu ortamlardan bazıları bunu destekleyip, kişiyi zorlayıcı ve motive edici olurken bazıları engelleyici olur.

Beklenti Kuramı incelendiğinde Vroom ilk bakılması gereken isimdir. Vroom'un teorisi değerlik, yararlılık ve beklenti kavramları etrafında oluşturulur. ${ }^{15}$ Çalışanlar işle ilgili çeşitli davranışlarını değerlendirirler (çok çalışmak) ve bu davranışlar içinden onları en çok ödül ve sonuca (terfi) götürecek olan davranışı seçerler.

\section{İş Doyumuna Etki Eden Faktörler}

İs doyumuna etki eden faktörleri bireysel ve örgütsel faktörler olmak üzere iki ana başlık altında incelemek mümkün olacaktır. Bireysel faktörler başlığı altında daha çok yaş, cinsiyet, eğitim düzeyi, medeni durum, unvan gibi kişiden kişiye farklılık gösterebilen özelliklere yer verilebileceği gibi

\footnotetext{
${ }^{13}$ Stephen Dugguh ve Ayaga Dennis, "Job Satisfaction Theories: Traceability to Employee Performance in Organizations," Journal of Business and Management 5, say1: 16 (2014): 11-18.

${ }^{14}$ Clayton P. Alderfer, Existence, Relatedness and Growth (New York: Free Press, 1972).

${ }^{15}$ Victor H. Vroom, Work and Motivation (New York: Wiley, 1964).
}

Üsküdar Üniversitesi Sosyal Bilimler Dergisi, 2019; sayl: 9 , $347-377$ 


\section{Merve BAŞ, Melisa AKSU, Hüseyin ÜNÜBOL ve Gökben HIZLI SAYAR}

örgütsel faktörler başlığı altında da ücret, yükselme olanakları, çalışma koşulları, çalışma süreleri, iletişim gibi çalışılan örgütlere bağlı faktörlerden bahsedilebilir.

\section{Bireysel Faktörler}

Yaş: Yapılan literatür taramasında mevcut araştırmaların birçoğunda yaş ile iş doyumu arasında bir ilişki olduğu görülmüştür. Yaş ilerledikçe iş doyumunun da artması pek çok araştırmada görülen bir durumdur. Clark vd. çalışmalarında yaş ve iş doyumu arasında $U$ şeklinde bir ilişkinin olduğu sonucuna varmışlardır. ${ }^{16}$ Orta yaşlarda en düşük noktaya inen iş doyumunun daha sonra yaş ilerledikçe yükseldiğini belirtmişlerdir. Literatürde iş doyumunun yaş değişkenine göre değiştiğini gösteren pek

Üsküdar University Journal of Social Sciences, 2019; issue: 9 , $347-377$ çok araştırma varken böyle bir değişimin olmadığını gösteren araştırmalara da rastlamak mümkündür. Kıyan vd. İstanbul Tıp Fakültesi'nde çalışan hekimlerle yaptıkları araştırmada iş doyumunun yaşa göre değişmediği sonucuna ulaşmışlardır.

Cinsiyet: Cinsiyete göre de bireylerin iş doyumlarında değişiklikler olduğunu gösteren araştırmalar vardır. Ancak cinsiyete göre iş doyum düzeylerinin değişmediğini gösteren araştırmalar da mevcuttur. Kırel, iş doyumunun kadın ve erkek ayrımından çok beklenti düzeyiyle alakalı olduğunu belirtmiştir. ${ }^{17}$ Yapılan karşılaştırmalı çalışmalar sonucunda kadın ve erkekleri farklı içsel motivasyon unsurlarının motive ettiği bulunmuştur. Buradan yola çıkarak kadın ve erkek arasındaki iş doyumu farklılıklarının onları motive eden unsurların birbirinden farklı olmasından kaynaklanabiliyor olabileceği söylenebilir.

Medeni Durum: Evli veya bekar olma ile iş tatmini arasındaki ilişkiye bakıldığında evlilerin iş tatmininin bekarlara oranla daha yüksek

\footnotetext{
${ }^{16}$ Andrew Clark, Andrew Oswald ve Peter Warr, "Is Job Satisfaction U-Shaped in Age?," Journal of Occupational and Organizational Psychology, sayı: 69 (1996): 57-81.

${ }^{17}$ Çiğdem Kırel, "Esnek Çalışma Saatleri Uygulamalarında Cinsiyet, İş Tatmini ve İş Bağlılığı İlişkisi,” İ. Ü. İşletme Fakültesi Dergisi 2, sayı: 28 (1999): 115-136.
} 
Akademisyenlerde İş Doyumunun Algılanan Sosyal Destekle İlişkisi

olduğuna dair bulgular dikkat çekmektedir. ${ }^{18}$ Özaydın ve Özdemir, banka personeliyle yaptıkları araştırmalarında Minnesota İş Doyumu Ölçeğinin iç kaynaklı tatmin boyutunda evli ve bekarların iş tatmin düzeyleri arasında anlamlı bir farklılık bulurken dış kaynaklı ve ölçeğin geneli itibariyle iş tatmini düzeylerinde farklılık bulmamışlardır. Cenkseven ve Dost öğretim elemanlarıyla yaptıkları çalışmada evli öğretim elemanlarının iş doyum düzeylerinin bekâr öğretim elemanlarına göre daha yüksek olduğu sonucuna varırken ${ }^{19}$, Öztürk ve Şahbudak ise Cumhuriyet Üniversitesi akademisyenleriyle yaptıkları araştırmalarında evli ve bekârlar arasında iş doyum düzeylerinin farklılaşmadığı sonucuna ulaşmışlardır.

Unvan: Yapılan literatür taramasıyla birlikte unvanla birlikte iş doyumunun da arttığını gösteren birçok araştırmaya rastlamak mümkündür. Hotamışlı ve Ağca öğretim elemanlarıyla yaptıkları $\operatorname{araştırmada~}^{20}$ Dr. Araştırma/Dr. Öğretim Görevlilerinin en düşük iş doyum düzeyine, profesörlerin ise en yüksek iş doyum düzeyine sahip olduğu sonucuna varmışlardır. Oshagbemi de genel iş doyum düzeyinin alınan unvanlarla birlikte arttı̆̆ını belirtmiştir. Yine akademisyenlerle yapılan bir başka araştırmada da aynı sonuca ulaşılmıştır. Öztürk ve Şahbudak'ın yaptıkları araştırmada unvan açısından en yüksek iş doyumuna sahip grup profesörlerdir. Özaydın ve Özdemir yaptıkları araştırmada Minnesota İş Doyumu Ölçeğinin iç kaynaklı ve genel doyum boyutunda unvan arttıkça iş doyumunda artış olduğunu belirtirlerken dış

\footnotetext{
${ }^{18}$ Mehmet Merve Özaydın ve Ömer Özdemir, "Çalışanların Bireysel Özelliklerinin İş Tatmini Üzerindeki Etkileri: Bir Kamu Bankası Örneği,” İşletme Araştırmaları Dergisi 1, say1: 6 (2014): 251-281.

${ }^{19}$ Fulya Cenkseven ve Meliha Tuzgöl Dost, “Öğretim Elemanlarının Sosyodemografik Değişkenlere ve Üniversitelerini Değerlendirmelerine Göre İş Doyumları,” Eğitim ve Bilim 148, sayı: 33 (2008): 28-39.

${ }^{20}$ Mustafa Hotamışlı ve Veysel Ağca, “Öğretim Elemanları İş Tatmin Düzeylerinin Demografik Özelliklere Göre Değişmesi: Türkiye’de Kamu ve Vakıf Üniversitelerinde Karşılaştırmalı Bir Araştırma,” Sosyal Bilimler Dergisi 2, sayı: 12 (2010): 95-118.
}

Üsküdar Üniversitesi Sosyal Bilimler Dergisi, 2019; sayl: 9 , $347-377$ 


\section{Merve BAŞ, Melisa AKSU, Hüseyin ÜNÜBOL ve Gökben HIZLI SAYAR}

kaynaklı tatmin boyutunda anlamlı bir farklılık bulmamışlardır. Akman vd. (2007) 203 öğretim elemanıyla yaptıkları araştırmada unvanı yüksek olanların unvanı daha düşük olanlara göre daha yüksek iş doyumuna sahip oldukları sonucuna varmışlardır. Ancak aynı zamanda bunun tam tersi sonuca ulaşan araştırmalara rastlamak da mümkündür.

\section{Örgütsel Faktörler}

Ücret: Ücret iş doyumuna etki eden en önemli örgütsel faktörler arasında gösterilebilir. Çalışan bireylerin verdikleri emeğin karşılığını gösteren unsurlardan biridir ücret. Dolayısıyla bireylerin çalışmalarının karşılığında bekledikleri ücreti alıp/alamamalarının onların iş doyumunu etkilediği düşünülmektedir. Bireylerdeki maddi doyumsuzluk

Üsküdar University Journal of Social Sciences, 2019; issue: 9 , $347-377$ performansın düşmesi, işten ayrılma, devamsızlıkta artış ve işin tümünden duyulan doyumsuzluk seviyesini yükseltmektedir. Buradan yola çıkarak alınan ücretin yetersizliğinin örgütler tarafından olumsuz olarak değerlendirilebilecek bazı sonuçlara yol açabileceği yorumunu yapmak mümkün olacaktır.

Yükselme Olanakları: Örgütler içerisindeki yükselme olanakları da çalışanlar açısından önem arz eden konulardan bir tanesidir. Birçok kişi için çalıştıkları işlerdeki yükselme olanakları önemlidir, çünkü örgüt içerisindeki yükselme aynı zamanda çalışanlara ücret gibi başka açılardan da olumlu olanaklar sağlayacaktır. Bu durumda yükselme olanağı ve ücreti birbiriyle ilişkili olarak görmek mümkün olabilir. Örgüt içerisinde yükselmek, aynı zamanda bireyin statüsünü de yükseltecek ve ona daha fazla saygınlık kazandıracaktır. Bu açıdan bakıldığında örgütler içerisindeki yükselme olanaklarının birçok başka değişkenle de ilişkili olabileceği yorumunu yapmak mümkün olabilir.

İletişim: İletişim yaşamın her alanında büyük bir önem taşıdığı gibi iş hayatında da büyük bir önem taşımaktadır. Bireylerin etraflarındaki kişilerle sağlıklı bir iletişim içerisinde olmalarının onlara psikolojik açıdan olumlu katkıları olduğu bilinmektedir. Vakitlerinin büyük bir kısmını 
Akademisyenlerde İ̧̧ Doyumunun Algılanan Sosyal Destekle İlişkisi

iş yerinde geçiren bireyler için çalıştıkları iş yerlerindeki kişilerle iyi bir iletişim halinde olmaları onların iş doyumunu arttırabilmektedir.

\section{Sosyal Destek ve Algılanan Sosyal Destek}

Sosyal desteğin insan hayatındaki yeri her açıdan bakıldığında büyük bir önem taşımaktadır ve bu alanda yapılan çalışmaların sayısı hızla artmaktadır. İnsan doğum anından itibaren etrafındaki kişilerle iletişim halinde olur ve çevresindeki bu kişilerle iletişim kurarak sosyalleşir. Kişinin etrafındaki kişilerle kuracağı sağlıklı bir iletişim ve bu kişilerden destek görmesi o kişinin gelişimine olumlu katkılar sağlayacaktır. Psikoloji alanına baktığımızda da sosyal olmanın, kişilerin ruhsal sağlığı açısından da olumlu etkileri olduğunu görebilmekteyiz. Öyle ki sosyal olarak daha izole olan bireyler psikolojik ve fiziksel olarak daha sağlıksızdırlar ve ölüm olasılıkları daha yüksektir. ${ }^{21}$ Cohen ve Wills, birçok araştırmanın sonucuna göre sosyal desteğin psikolojik ve fiziksel sağlıkla ilişkili olduğundan bahsetmişlerdir. Cassel ve Cobb insan ve hayvanlarla ilgili otuzdan fazla araştırmayı gözden geçirmelerinin sonucunda sosyal ilişkilerin sağlık için koruyucu olduğunu bulmuşlardır. Dolayısıyla sağlık ve sosyal destek birbiriyle böyle ilişkili iki kavramken, bu konu daha da büyük bir önem kazanmaktadır ve bu alanda yapılan araştırmaların sayısı hız kazanmaktadır. Literatürdeki sosyal destekle ilgili olan tanımlar sosyolojik, psikolojik ve iletişim bakış açısı olmak üzere üç bakış açısına göre tanımlanmışlardır. Bunlardan ilki sosyolojik bakış açısıdır. Bireylerin sosyal gruplara ne derecede dahil olduğuna odaklanır. İkincisi psikolojik bakış açısıdır ve desteğin algılanan ulaşılabilirliğine odaklanır. Üçüncüsü ise iletişim bakış açısıdır. Bu bakış açısı da desteği sağlayanlar ve desteği alanlar arasında oluşan etkileşime odaklanır. ${ }^{22}$

\footnotetext{
${ }^{21}$ James S. House, Karl R. Landis ve Debra Umberson, “Social Relationships and Health," Science 4865, say1: 241 (1988): 540-545.

${ }^{22}$ Anita L. Vangelesti, “Challenges in Conceptualizing Social Support,” Journal of Social and Personal Relationships 1, say1: 26 (2009): 39-51.
}

Üsküdar Üniversitesi Sosyal Bilimler Dergisi, 2019; sayl: 9 , $347-377$ 


\section{Merve BAŞ, Melisa AKSU, Hüseyin ÜNÜBOL ve Gökben HIZLI SAYAR}

Sosyal destek fikri 1970’lerin ortalarında büyük bir değer kazanmıştır ve bu konuyla ilgili araştırmalara son 30 yılda daha çok odaklanılmıştır. Cohen ve Wills tarafindan öne sürülen temel etki modeli ve tampon etki modeli olmak üzere sosyal desteğin kişiyi strese, olumsuz sonuçlarına ve hastalıklara karşı nasıl ve neden etkilediğini açıklamada yardımcı olan ve sosyal destekle sağlık arasındaki ilişkinin incelenmesiyle ilgili olan iki temel teori bulunmaktadır. Tampon etkisi modeline göre destek, iyi olma haliyle sadece kişi stres altındayken ilişkilidir. Destek, kişiyi stresli olayların hastalığa yol açan etkilerinden korur (tampon görevi görür). Yani stresli bir durumla karşılaşılması durumunda destek, tampon görevi görecektir. Diğer model olan temel etki modeline göre kişi, ister stres altında olsun ister olmasın sosyal kaynaklar faydalıdır. ${ }^{23}$

Üsküdar

University Journal of Social Sciences, 2019; issue: 9 , $347-377$

İnsanların yaşamında önemli bir yeri olan, gerektiğinde bireye duygusal, maddi ve zihinsel (bilişsel) yardım sağlayan tüm kişiler arası ilişkiler, sağlığı korumaya yarayan "Sosyal Destek Sistemleri” olarak tanımlanır. ${ }^{24}$ Maddi destek, "günlük sorumlulukların gerçekleştirilmesi için başkaları tarafından sağlanan eylem ya da araçlardır". ${ }^{25}$ Duygusal destek, kişinin sevgi, şefkat, güven, ilgi, empati ve bir gruba ait olması gibi temel sosyal gereksinimleri içerir. Zihinsel (bilişsel) destek ise bireyin sorunlarını çözmesine yardım edecek bilgi olarak tanımlanır. Kişiler sosyal desteği aileden, eşten ya da arkadaştan görüyor olabilirler. En önemli sosyal destek kaynağı ise ailelerdir. Bunun yanı sıra arkadaş desteği de ruhsal sağlık için önemlidir. Sosyal destek ağları formal ve informal olmak üzere ikiye

\footnotetext{
${ }^{23}$ Sheldon Cohen ve Thomas A. Wills, “Stress, Social Support and Buffering Hypothesis," Pschological Bulletin 2, say1: 98 (1995): 310-357.

${ }^{24}$ Melek Ardahan, “Sosyal Destek ve Hemşirelik," Atatürk Üniversitesi Hemşirelik Yüksekokulu Dergisi 2, say1: 9 (2006): 68-75.

${ }^{25}$ Özlem Bayraktar, "Üniversite Öğrencilerinin Algılanan Sosyal Destek Düzeyleri ile Duygusal Zekâları Arasındaki İlişkinin İncelenmesi,” (Yayımlanmamış Yüksel Lisans Tezi, Selçuk Üniversitesi Eğitim Bilimleri Enstitüsü, Konya, 2011).
} 
Akademisyenlerde İ̧̧ Doyumunun Algılanan Sosyal Destekle İlişkisi

ayrılabilir. Formal sosyal destek ağları kişinin müdürüyle, akranlarıyla olan ilişkisini içerirken informal sosyal destek ağları kişinin ailesi ve arkadaşları arasındaki bağı ifade eder. ${ }^{26}$

Son yıllarda sosyal destek alanında yapılan araştırmalarda ağırlık, sosyal ilişkilerin yeterince destekleyici olup olmadığıyla ilgili kişinin genel izlenimlerine yani algılanan sosyal desteğe kaymıştır. Bir başka tanıma göre, algilanan sosyal destek kişilerin değer verildiğini ve sevildiklerini hissetmelerini ve önemli diğer kişilerle ilişkilerinde iyi olduklarını hissetmelerini kapsar. ${ }^{27}$ Algilanan destek, kişilik özellikleri, tutum ve mizaçtan da etkilenebilmektedir. Başka bir deyişle algılanan sosyal destekte sosyal desteğin nasıl algılandığına dair kişinin kendi görüşleri etkili olduğu için kişilik özellikleri, tutum ve mizacında bu algılamaya etki etmesi muhtemeldir.

Ayrıca yapılan bazı araştırmalar sosyal desteğin iş doyumu konusunda da oldukça önemli olduğunu göstermiştir. Sosyal destek iş doyumunu tahmin etmede temel bir kaynaktır. Harris vd. yapılan araştırmaların sonuçlarının iş yerindeki sosyal desteğin yüksek bir iş doyumuyla ilişkili olduğunu gösterdiğini belirtmişlerdir. Ayrıca iş yerinde sosyal desteğin cinsiyete göre de değişiklik gösterebildiğinden bahsetmişlerdir. Taylor vd. yaptıkları araştırmada kadınların iş yerindeki sosyal desteğe erkeklerden daha fazla değer verdiği sonucuna ulaşmışlardır. Ayrıca özellikle süpervizör sosyal desteği, çeşitli iş ortamlarında işe bağlı stresin olumsuz sonuçlarını hafifletmek olarak tanımlanmaktadır. Araştırmalar hem iş doyumunu hem de algılanan sosyal desteği çalışanın aynı işte kalmasında

\footnotetext{
${ }^{26}$ Safia Bano vd., "Does Perceived Social Support Mediate The Relationship of Perceived Organizational Support and Job Satisfaction?, Journal of Managerial Sciences 3, say1: 11 (2017): 105-118.

${ }^{27}$ Ramin Aliyev ve Erhan Tunç, “Ortaokul Öğrencilerinin Algılanan Sosyal Destek Düzeyi ve Benlik Algılarının İncelenmesi,” Atatürk Üniversitesi Sosyal Bilimler Enstitüsü Dergisi 2, say1: 21 (2017): 401-418.
} 


\section{Merve BAŞ, Melisa AKSU, Hüseyin ÜNÜBOL ve Gökben HIZLI SAYAR}

öngörücü olarak tanımlamıştır. Brough ve Pears iş yerindeki sosyal desteğin işbirlikçi problem çözme ve bilgi paylaşma, durumları yeniden değerlendirme ve iş arkadaşları, süpervizörler ve yöneticiler gibi çeşitli personelden tavsiye toplamaya odaklandığını belirtmişlerdir. ${ }^{28}$ Singh vd. sosyal destekten, olumlu bireysel ve örgütsel sonuçlarla ilişkili önemli bir kaynak olarak bahsetmişlerdir. Anlaşıldığı üzere algılanan sosyal destekle iş doyumu arasındaki ilişkinin önemli olduğunu vurgulayan araştırmalar mevcuttur. Günümüzde sosyal destek ve algılanan sosyal destekle ilgili araştırmalar her ne kadar hız kazanmış olsa da literatürde bu konuyla ilgili akademisyenler üzerinde yapılan araştırmaların sayısının çok fazla olmadığı göze çarpmaktadır.

Üsküdar

University Journal of Social Sciences, 2019; issue: 9 , $347-377$

Sosyal desteğin bireylerin hayatının her alanında böyle büyük bir öneme sahip olması bu alanda yapılan çalışmaların da hızlanmasına sebep olurken bazı araştırmacılar bireylerin algıladıkları sosyal desteği ölçmek amacıyla çeşitli ölçekler geliştirmişlerdir. Zimet vd. bu amaçla Çok Boyutlu Algılanan Sosyal Destek Ölçeğini geliştirmişlerdir. ${ }^{29}$

Günümüzde iş doyumu önemli bir konu olarak değerlendirilmektedir ve konuyla ilgili yapılan araştırmalar oldukça fazladır. Aynı zamanda sosyal destek ve algılanan sosyal destek de bireylerin yaşamındaki etkisiyle birlikte önem taşıyan bir konudur. Bu araştırma kapsamında toplumların daha iyi yerlere gelebilmesi için gerekli olan akademisyenlerin iş doyumuyla, algılanan sosyal destek düzeyleri arasındaki ilişkinin incelenmesi amaçlanmıştır. Akademisyenlerin iş doyumuna etki eden faktörleri anlamak bu alanlardaki eksikliklerin giderilmesine de katkı sağlayabilir. Konuyla ilgili literatür taraması yapıldığında akademisyenlerde iş

\footnotetext{
${ }^{28}$ Paula Brough ve Judi Pears, "Evaluating The Influence of The Type of Social Support On Job Satisfaction and Work Related Psychological Well-Being," International Journal of Organizational Behaviour 2, say1: 8 (2004): 472-485.

${ }^{29}$ Gregory D. Zimet, “The Multidimensional Scale of Perceived Social Support,” Journal of Personality Assessment 1, say1: 52 (1998): 30-41.
} 
Akademisyenlerde İş Doyumunun Algılanan Sosyal Destekle İlişkisi

doyumunu inceleyen pek çok araştırmaya rastlamak mümkündür. Ancak akademisyenlerdeki iş doyumuyla algılanan sosyal destek arasındaki ilişkiyi inceleyen çok fazla araştırma olmadığı görülmektedir. Bu amaçla araştırmanın literatüre katkı sağlaması da amaçlanmıştır.

\section{Yöntem}

Araştırmanın evrenini Üsküdar Üniversitesi akademisyenleri oluşturmaktadır. Araştırma kapsamında Üsküdar Üniversitesi'nde bulunan tüm akademik personele ulaşılmaya çalışılmış olup çalışmaya geri dönüşü 84 kişi yapmıştır. Araştırmanın örneklemini üniversitede görev yapmakta olan 84 gönüllü katılımcı oluşturmaktadır. Araştırmaya katılan akademisyenlerden 62'sini kadın, 22'sini erkek katılımcılar oluşturmaktadır.

$\mathrm{Bu}$ araştırma, ilişkisel tarama modelli bir çalışmadır. Araştırmada Üsküdar Üniversitesi'nde bulunan akademisyenlerin iş doyumunun algılanan sosyal destekle olan ilişkisinin yanı sıra; iş doyumunun ve algılanan sosyal destek düzeylerinin yaş, cinsiyet, unvan, medeni durum, mesleki kıdem, yürütülen lisansüstü tez sayısı, akademisyenlik durumu, haftada verilen ders saati, ailede akademisyenlik durumu ile ilişkisine de bakılmıştır.

Araştırma deseni Üsküdar Üniversitesi Girişimsel Olmayan Araştırmalar Etik Kurulu tarafindan onaylanmıştır.

\section{Veri Toplama Araçları:}

\section{a. Sosyodemografik Veri Formu:}

Katılımcılara ilk olarak araştırmacı tarafından oluşturulan Sosyodemografik Veri Formu sunulmuştur. Sosyodemografik Veri Formunun amacı uygulanan ölçeklere katkı sağlayan bireyler hakkında daha detaylı bilgi edinmektir. Aynı zamanda iş doyumu ve algılanan sosyal desteğin sosyodemografik verilerle olan ilişkisini incelemektir. Formdaki sorular ölçeklerden elde edilen bilgileri pekiştirmek ve istenilen verileri 


\section{Merve BAŞ, Melisa AKSU, Hüseyin ÜNÜBOL ve Gökben HIZLI SAYAR}

tamamlamak amacıyla oluşturulmuştur. Bu kapsamda katılımcılardan yaş, cinsiyet, unvan, medeni durum, mesleki kıdem, yürütülen lisansüstü tez sayıları, akademisyenlik durumu, ailede akademisyenlik durumu, haftada verilen ders saati gibi bilgiler istenmiştir.

\section{b. Minnesota İş Doyumu Ölçeği:}

Minnesota İş Doyumu Ölçeği (MIDÖ) 1967 yllında Weiss ve arkadaşları tarafından geliştirilmiştir. Ölçeğin uzun ve kısa olmak üzere iki farklı formu vardır. Uzun form 100 sorudan oluşurken kısa form 20 sorudan oluşur. Bu araştırmada ölçeğin kısa şekli kullanılmıştır. Soruların cevapları 5'li likert tipi cevaplardan oluşmaktadır. Aynı zamanda ölçeğin uygulanması az bir zaman alır. Uzun form 15-20 dakika gibi bir süre alırken

Üsküdar University Journal of Social Sciences, 2019; issue: 9 , $347-377$ kısa form 5 dakika gibi bir süre alır. MİDÖ’nün Türkçeye uyarlanması Baycan tarafından yapılmıştır. MiDÖ’nün kısa formu içsel doyum, dışsal doyum ve genel doyum olmak üzere üç alt ölçekten oluşur. MíDÖ’den alınan puanlar hesaplandıktan sonra genel iş doyumu puanı 20-100 arasında olmaktadır. Yüzdelik değer olarak bakıldığında $\% 25$ ve altı düşük iş doyumunu, \%26-74 arası orta iş doyumunu, \%75 ve üzere yüksek iş doyumunu ifade etmektedir. ${ }^{30}$

\section{c. Çok Boyutlu Algılanan Sosyal Destek Ölçeği:}

Çok Boyutlu Algılanan Sosyal Destek Ölçeği (ÇBASDÖ) Zimet ve arkadaşları tarafından geliştirilmiştir. 12 maddeden oluşmaktadır ve 7’li likert tipi cevapları içermektedir. Ölçekten elde edilen puanın yüksek olması algılanan sosyal desteğin de yüksek olduğunu ifade etmektedir. "Önerilen alt ölçek yapısı; aile, arkadaşlar ve özel bir insandan alınan algılanan desteği içermektedir”. Ölçek Türkçeye Arkar ve Eker tarafından

\footnotetext{
${ }^{30}$ David J. Weiss, Rene V. Dawis, George W. England ve Lloyd H. Lofquist, Manual for the Minnesota Satisfaction Questionnaire (Minneapolis: University of Minnesota, Industrial Relations Center, 1967)
} 
Akademisyenlerde İş Doyumunun Algılanan Sosyal Destekle İlişkisi

çevrilmiştir ve faktör yapısı, güvenirliği ve yapı geçerliği ve ülkemizde kullanımı açısından genel olarak tatmin edici bulunmuştur. ${ }^{31}$

\section{Veri Analizi}

Elde edilen bilgilerin analizi için; SPSS (Statistical Package Program for Social Science) versiyon 21.0 programı kullanılmıştır. Sosyodemografik Bilgi ve Veri Formunda yer alan değişkenlerin dağılımlarını tespit etmek amacıyla Frekans Analizi kullanılmıştır. Uygulanan ölçekler ile Sosyodemografik Bilgi ve Veri Formunda yer alan değişkenler arasındaki ilişkiyi saptamak için Tek Yönlü Varyans Analizi (ANOVA) ve Bağımsız Gruplarda T-Testi Analizinden yararlanılmıştır. Ölçeklerin kendi aralarındaki ilişkiyi tespit edebilmek amacıyla ise Pearson Korelasyon Analizi kullanılmıştır.

\section{Bulgular}

Araştırmada yer alan 84 katılımcının cinsiyet değişkenine göre dağılımları incelendiğinde; 62 (\%73,8) kadın, 22 (\%26,2) erkek olduğu görülmektedir. Katılımcılardan 16 (\%19) kişi 20-30 yaş, 31 (\%36,9) kişi 31-40 yaş, 22 (\%26,2) kişi 41-50 yaş, 9 (\%10,7) kişi 51-60 yaş ve $6(\% 7,1)$ kişi 61 yaş ve üzeri grubunda yer almaktadır. Katılımcıların medeni duruma göre dağılımları incelendiğinde; 45 (\%53,6) kişinin evli, $31(\% 36,9)$ kişinin bekar, $8(\% 9,5)$ kişinin boşanmış veya dul olduğu görülmektedir. Mesleki kıdeme yönelik dağılım incelendiğinde; 24 $(\% 28,6)$ kişi 5 yıl ve daha az, 12 (\%14,3) kişi 6-10 yıl, 12 (\%14,3) kişi 11-15 yıl, 15 (\%17,9) kişi 16-20 yıl, 21 (\%25) kişi 21 yıl ve daha fazla zamandır mesleki kıdeme sahiptir. Katılımcılardan 34 (\%40,5) kişi öğretim görevlisi, $10(\% 11,9)$ kişi araştırma görevlisi, 25 (\%29,8) kişi yardımcı doçent, 5 (\%6) kişi doçent ve $10(\% 11,9)$ kişi profesör unvanına sahiptir. Araştırmaya katılan 84 akademisyenden 20 (\%23,8)'sinin

${ }^{31}$ Gregory D. Zimet, “The Multidimensional Scale of Perceived Social Support,” Journal of Personality Assessment 1, say1: 52 (1998): 30-41. 


\section{Merve BAŞ, Melisa AKSU, Hüseyin ÜNÜBOL ve Gökben HIZLI SAYAR}

yarı zamanlı, $64(\% 76,2)$ 'ünün tam zamanlı olduğu saptanmıştır. Katılımcılardan $23(\% 27,4)$ kişinin ailelerinde akademisyen varken, 61 $(\% 72,6)$ kişinin ailelerinde akademisyen olmadığı görülmektedir. Haftada verilen ders saatine yönelik dağılım incelendiğinde 54 (\%64,3) kişinin 15 saatten az, $30(\% 35,7)$ kişinin 15 saatten fazla ders verdikleri saptanmıştır. Yürütülen lisansüstü tez sayısına yönelik dağılım incelendiğinde 63 (\%75) kişinin 5 'ten az, 21 (\%25) kişinin ise 5 ve daha fazla sayıda lisansüstü tez yürüttükleri görülmektedir.

İş doyumu ve algılanan sosyal destek arasındaki ilişkinin incelenmesi amacıyla yapılan Pearson Korelasyon Analizi sonuçları Tablo 1'te verilmiştir.

Tablo 1: Ölçekler Arasında Yapılan Pearson Korelasyon Analizi Sonuçları

Üsküdar

University

Journal

of Social

Sciences, 2019;

issue: 9 ,

347-377

\begin{tabular}{|l|c|c|c|c|c|c|c|c|}
\hline \multicolumn{2}{|l|}{} & $\mathbf{1}$ & $\mathbf{2}$ & $\mathbf{3}$ & $\mathbf{4}$ & $\mathbf{5}$ & $\mathbf{6}$ & $\mathbf{7}$ \\
\hline $\begin{array}{l}\text { MiDÖ-Genel } \\
\text { Doyum }\end{array}$ & $\mathrm{r}$ & 1 & & & & & & \\
\hline $\begin{array}{l}\text { MíDÖ-İçsel } \\
\text { Doyum }\end{array}$ & $\mathrm{r}$ & $0,903^{* *}$ & 1 & & & & & \\
\hline $\begin{array}{l}\text { MİDÖ-Dişsal } \\
\text { Doyum }\end{array}$ & $\mathrm{r}$ & $0,860^{* *}$ & $0,557^{* *}$ & 1 & & & & \\
\hline $\begin{array}{l}\text { ÇBASDÖ-Aile } \\
\text { Destek }\end{array}$ & $\mathrm{r}$ & 0,000 & $-0,077$ & 0,092 & 1 & $\mathrm{r}$ & & \\
\hline $\begin{array}{l}\text { ÇBASDÖ- } \\
\text { Arkadaş Destek }\end{array}$ & $\mathrm{r}$ & 0,078 & 0,059 & 0,081 & $0,332^{* *}$ & 1 & & \\
\hline $\begin{array}{l}\text { ÇBASDÖ-Diğer } \\
\text { Önemli Kişi } \\
\text { Destek }\end{array}$ & $\mathrm{r}$ & 0,164 & 0,078 & $0,223^{*}$ & $0,362^{* *}$ & $0,547^{* *}$ & 1 & \\
\hline $\begin{array}{l}\text { ÇBASDÖ } \\
\text { Toplam }\end{array}$ & $\mathrm{r}$ & 0,119 & 0,040 & 0,183 & $0,657^{* *}$ & $0,796^{* *}$ & $0,873^{* *}$ & 1 \\
\hline
\end{tabular}

${ }^{*} p<0,05$ : Istatistiksel olarak anlamlı

${ }^{* *} p<0,01$ : Istatistiksel olarak anlamlı 
Akademisyenlerde İ̧̧ Doyumunun Algılanan Sosyal Destekle Illişkisi

Korelasyon sonuçlarına göre; MiDÖ-Genel Doyum ile MiDÖ-İçsel Doyum ( $\mathrm{r}=0,903 ; p=0,000)$ ve MİDÖ-Dışsal Doyum $(\mathrm{r}=0,860 ; p=0,000)$ arasında istatistiksel olarak anlamlı ve pozitif yönde bir ilişki vardır. Diğer taraftan MIDÖ-Genel Doyum ile ÇBASDÖ-Aile Destek ( $r=0,000$; $p=0,998)$, ÇBASDÖ-Arkadaş Destek ( $\mathrm{r}=0,078 ; p=0,479)$, ÇBASDÖDiğer Önemli Kişi Destek $(\mathrm{r}=0,164 ; p=0,137)$ ve ÇBASDÖ Toplam $(\mathrm{r}=0,119 ; p=0,282)$ arasında anlamlı bir ilişki saptanmamıştır $(p>0,05)$.

MİDÖ-İçsel Doyum ile MİDÖ-Dışsal Doyum ( $\mathrm{r}=0,557 ; p=0,000)$ arasında istatistiksel olarak anlamlı ve pozitif yönde bir ilişki vardır. Öte yandan MİDÖ-İçsel Doyum ile ÇBASDÖ-Aile Destek ( $\mathrm{r}=-0,077$; $p=0,488)$, ÇBASDÖ-Arkadaş Destek ( $\mathrm{r}=0,059$; $p=0,596)$, ÇBASDÖDiğer Önemli Kişi Destek $(\mathrm{r}=0,078 ; p=0,480)$ ve ÇBASDÖ Toplam $(\mathrm{r}=0,040 ; p=0,721)$ arasında anlamlı bir ilişki saptanmamıştır $(p>0,05)$.

MİDÖ-Dışsal Doyum ile ÇBASDÖ-Diğer Önemli Kişi Destek $(\mathrm{r}=0,223 ; p=0,041)$ arasında istatistiksel olarak anlamlı ve pozitif yönde bir ilişki saptanmışken, ÇBASDÖ-Aile Destek ( $\mathrm{r}=0,092 ; p=0,408)$, ÇBASDÖ-Arkadaş Destek $(r=0,081 ; \mathrm{p}=0,461)$ ve ÇBASDÖ Toplam $(\mathrm{r}=0,183 ; \mathrm{p}=0,096)$ arasında anlamlı bir ilişki saptanmamıştır $(\mathrm{p}>0,05)$.

ÇBASDÖ-Aile Destek ile ÇBASDÖ-Arkadaş Destek ( $r=0,332$; $\mathrm{p}=0,002)$, ÇBASDÖ-Diğer Önemli Kişi Destek $(r=0,362 ; \mathrm{p}=0,001)$ ve ÇBASDÖ Toplam ( $r=0,657$; $\mathrm{p}=0,000)$ arasında istatistiksel olarak anlamlı ve pozitif yönde bir ilişki vardır. ÇBASDÖ-Arkadaş Destek ile ÇBASDÖDiğer Önemli Kişi Destek $(r=0,547 ; \mathrm{p}=0,000)$ ve ÇBASDÖ Toplam $(\mathrm{r}=0,796 ; \mathrm{p}=0,000)$ arasında istatistiksel olarak anlamlı ve pozitif yönde bir ilişki saptanmıştır. ÇBASDÖ-Diğer Önemli Kişi Destek ile ÇBASDÖ Toplam $(\mathrm{r}=0,873 ; \mathrm{p}=0,000)$ arasında istatistiksel olarak anlamlı ve pozitif yönde bir ilişki saptanmıştır.

İş doyum ve algılanan sosyal destek düzeylerinin cinsiyete göre ortalamaları ve bu ortalamalar arasındaki farkın istatistiksel olarak anlamlı olup olmadığını incelemek amacıyla yapılan Bağımsız Gruplarda 


\section{Merve BAŞ, Melisa AKSU, Hüseyin ÜNÜBOL ve Gökben HIZLI SAYAR}

T-Testi Analizi sonuçlarına göre; MİDÖ-Genel Doyum, MİDÖ-Dışsal Doyum, ÇBASDÖ-Aile Destek, ÇBASDÖ-Arkadaş Destek ve ÇBASDÖ Toplam puanları cinsiyete göre farklılık göstermektedir $(p<0,05)$. Erkek katılımcıların MİDÖ-Genel Doyum ve MİDÖ-Dışsal Doyum puanları kadın katılımcılara göre anlamlı derecede farklı ve yüksektir. ÇBASDÖAile Destek, ÇBASDÖ-Arkadaş Destek ve ÇBASDÖ Toplam ise kadın katılımcılarda, erkek katılımcılara göre anlamlı derecede farklı ve yüksektir.

İş doyum ve algılanan sosyal destek düzeylerinin yaşa göre ortalamaları ve bu ortalamalar arasındaki farkın istatistiksel olarak anlamlı olup olmadığını incelemek amacıyla yapılan Tek Yönlü Varyans Analizi (ANOVA) sonuçlarına göre iş doyum ve algılanan sosyal destek düzeyleri

Üsküdar University Journal of Social Sciences, 2019; issue: 9 , $347-377$ yaşa göre anlamlı düzeyde farklılık göstermemektedir $(p>0,05)$.

İş doyum ve algılanan sosyal destek düzeylerinin medeni duruma göre ortalamaları ve bu ortalamalar arasındaki farkın istatistiksel olarak anlamlı olup olmadığını incelemek amacıyla yapılan Tek Yönlü Varyans Analizi (ANOVA) sonuçlarına göre MİDÖ-Genel Doyum ve ÇBASDÖ-Aile Destek ile medeni durum arasında anlamlı düzeyde bir fark bulunmaktadır. $(\mathrm{p}<0,05)$. Farklılığın hangi gruptan kaynaklandığını saptamak amacıyla yapılan Tukey Post-Hoc testi sonuçlarına göre; MiDÖ-Genel Doyum için; evli ve bekar arasındaki anlamlı ilişkiden kaynaklandığı görülmektedir. Evli katılımcıların MİDÖ-Genel Doyum puanlarının bekar katılımcılardan daha yüksek olduğu saptanmıştır.

ÇBASDÖ-Aile Destek için; evli ve bekar arasındaki anlamlı ilişkiden kaynaklandığı görülmektedir. Evli katılımcıların ÇBASDÖ-Aile Destek puanlarının bekar katılımcılardan daha yüksek olduğu saptanmıştır.

İş doyum ve algılanan sosyal destek düzeylerinin mesleki kıdeme göre ortalamalarını ve bu ortalamalar arasındaki farkın istatistiksel olarak anlamlı olup olmadığını incelemek amacıyla yapılan Tek Yönlü Varyans Analizi (ANOVA) sonuçları Tablo 2'de verilmiştir. 


\section{Akademisyenlerde İ̧ Doyumunun Algılanan Sosyal Destekle liliskisi}

\begin{tabular}{|c|c|c|c|c|c|c|}
\hline \multicolumn{2}{|c|}{ Tablo 2} & $\mathbf{N}$ & Ortalama & $\begin{array}{c}\text { Std. } \\
\text { Sapma }\end{array}$ & $\mathbf{F}$ & $\mathbf{p}$ \\
\hline \multirow{5}{*}{$\begin{array}{l}\text { MIDÖ- } \\
\text { Genel } \\
\text { Doyum }\end{array}$} & 5 yil ve daha az & 24 & 3,69 & 0,55 & \multirow{5}{*}{3,226} & \multirow{5}{*}{$0,017^{*}$} \\
\hline & 6-10 y1l & 12 & 3,57 & 0,71 & & \\
\hline & $11-15$ yll & 12 & 3,59 & 0,49 & & \\
\hline & $16-20 \mathrm{yll}$ & 15 & 3,92 & 0,51 & & \\
\hline & 21 yıl ve üzeri & 21 & 4,14 & 0,53 & & \\
\hline \multirow{5}{*}{$\begin{array}{l}\text { MİDÖ- } \\
\text { İçsel } \\
\text { Doyum }\end{array}$} & 5 yil ve daha az & 24 & 3,82 & 0,60 & \multirow{5}{*}{2,096} & \multirow{5}{*}{0,089} \\
\hline & 6-10 yil & 12 & 3,79 & 0,72 & & \\
\hline & $11-15$ yl & 12 & 3,96 & 0,59 & & \\
\hline & $16-20 \mathrm{yll}$ & 15 & 4,04 & 0,53 & & \\
\hline & 21 yll ve üzeri & 21 & 4,28 & 0,52 & & \\
\hline \multirow{5}{*}{$\begin{array}{l}\text { MİDÖ- } \\
\text { Dişsal } \\
\text { Doyum }\end{array}$} & 5 yil ve daha az & 24 & 3,50 & 0,62 & \multirow{5}{*}{3,980} & \multirow{5}{*}{$0,005^{*}$} \\
\hline & 6-10 y1l & 12 & 3,23 & 0,91 & & \\
\hline & $11-15$ yll & 12 & 3,03 & 0,63 & & \\
\hline & $16-20 \mathrm{yll}$ & 15 & 3,75 & 0,70 & & \\
\hline & 21 yll ve üzeri & 21 & 3,92 & 0,72 & & \\
\hline \multirow{5}{*}{$\begin{array}{l}\text { ÇBASDÖ- } \\
\text { Aile Destek }\end{array}$} & 5 yil ve daha az & 24 & 24,25 & 5,48 & \multirow{5}{*}{0,776} & \multirow{5}{*}{0,544} \\
\hline & 6-10 y1l & 12 & 23,00 & 4,63 & & \\
\hline & $11-15 \mathrm{yll}$ & 12 & 23,83 & 4,23 & & \\
\hline & $16-20$ yll & 15 & 25,73 & 3,43 & & \\
\hline & 21 yll ve üzeri & 21 & 25,00 & 3,75 & & \\
\hline \multirow{5}{*}{$\begin{array}{l}\text { ÇBASDÖ- } \\
\text { Arkadaş } \\
\text { Destek }\end{array}$} & 5 yil ve daha az & 24 & 23,04 & 4,85 & \multirow{5}{*}{0,660} & \multirow{5}{*}{0,622} \\
\hline & 6-10 yıl & 12 & 24,16 & 3,37 & & \\
\hline & $11-15$ yll & 12 & 25,91 & 3,80 & & \\
\hline & $16-20 \mathrm{yll}$ & 15 & 23,80 & 6,68 & & \\
\hline & 21 yll ve üzeri & 21 & 23,38 & 6,02 & & \\
\hline
\end{tabular}

Üsküdar Üniversitesi Sosyal Bilimler Dergisi, 2019; sayl: 9 , $347-377$ 


\section{Merve BAŞ, Melisa AKSU, Hüseyin ÜNÜBOL ve Gökben HIZLI SAYAR}

Üsküdar

University

Journal of Social

Sciences, 2019;

issue: 9 ,

347-377

\begin{tabular}{|c|c|c|c|c|c|c|}
\hline \multirow{5}{*}{$\begin{array}{l}\text { ÇBASDÖ- } \\
\text { Diğer } \\
\text { Önemli } \\
\text { Kişi Destek }\end{array}$} & 5 yil ve daha az & 24 & 22,00 & 7,63 & \multirow{5}{*}{1,717} & \multirow{5}{*}{0,155} \\
\hline & $6-10$ yıl & 12 & 17,91 & 8,50 & & \\
\hline & $11-15$ yil & 12 & 23,66 & 7,31 & & \\
\hline & $16-20$ yil & 15 & 24,40 & 6,15 & & \\
\hline & 21 yıl ve üzeri & 21 & 23,38 & 5,94 & & \\
\hline \multirow{5}{*}{$\begin{array}{l}\text { ÇBASDÖ } \\
\text { Toplam }\end{array}$} & 5 yil ve daha az & 24 & 69,29 & 11,38 & \multirow{5}{*}{0,974} & \multirow{5}{*}{0,427} \\
\hline & $6-10$ yıl & 12 & 65,08 & 14,00 & & \\
\hline & $11-15$ yll & 12 & 73,41 & 13,13 & & \\
\hline & $16-20$ yil & 15 & 73,93 & 13,20 & & \\
\hline & 21 yll ve üzeri & 21 & 71,76 & 15,19 & & \\
\hline
\end{tabular}

İş doyum ve algılanan sosyal destek düzeylerinin akademik unvana göre ortalamaları ve bu ortalamalar arasındaki farkın istatistiksel olarak anlamlı olup olmadığını incelemek amacıyla yapılan Tek Yönlü Varyans Analizi (ANOVA) sonuçlarına göre; iş doyum ve algılanan sosyal destek düzeyleri akademik unvana göre anlamlı düzeyde farklılık göstermemektedir $(\mathrm{p}>0,05)$.

İş doyum ve algılanan sosyal destek düzeylerinin akademisyenlik durumuna göre ortalamaları ve bu ortalamalar arasındaki farkın istatistiksel olarak anlamlı olup olmadığını incelemek amacıyla yapılan Bağımsız Gruplarda T-Testi Analizi sonuçlarına göre; iş doyum ve algılanan sosyal destek düzeyleri akademisyenlik durumuna göre anlamlı düzeyde farklılık göstermemektedir $(\mathrm{p}>0,05)$.

\section{Tartışma}

$\mathrm{Bu}$ çalışmada akademisyenlerdeki iş doyumunun algılanan sosyal destekle ilişkisinin incelenmesi amaçlanmıştır. Bu bilgiler zaten yöntem bölümünde verilmişti. 
Akademisyenlerde İ̧̧ Doyumunun Algılanan Sosyal Destekle İlişkisi

İş doyumuyla algilanan sosyal desteğin arasındaki ilişkinin incelenmesine yönelik korelasyon analizinde Minnesota İş Doyumu Ölçeği ile Dışsal Doyum ve ÇokBoyutlu Algılanan Sosyal Destek Ölçeğinin, diğer önemli kişi destek alt boyutlarında pozitif yönde ve anlamlı bir ilişkisi bulunmuştur. Ancak iki ölçek arasında bunun dışında kalan alt boyutlara bakıldığında herhangi bir ilişkinin olmadığı sonucuna ulaşılmıştır. $\mathrm{Bu}$ durumda çalışmanın hipotezinin kısmen doğrulandığını söylemek mümkün olacaktır. İş doyumu ve algılanan sosyal destek düzeylerinin sosyodemografik değişkenler açısından değişimi incelendiğinde bazı değişkenlerin ölçekten alınan puanlara etki ettiği bulunmuştur.

Cinsiyet açısından bakıldığında MiDÖ’nün genel doyum ve dışsal doyumunun erkek katılımcılarda daha yüksek olduğu görülmektedir. Sosyal destek açısından bakıldığında ise ÇBASDÖ’nün aile desteği, arkadaş desteği ve toplamlarının, kadın katılımcılarda daha fazla olduğu görülmektedir. $\mathrm{Bu}$ sonuçların literatürle uyumlu sonuçlar olduğu görülmektedir. Elde edilen bilgiler literatürle uyuşmaktadır. Yapılan pek çok araştırmada iş doyumunun cinsiyete göre değiştiğinden çalışma içerisinde bahsedilmiştir.

Medeni durum açısından bakıldığında ise MíDÖ-genel doyumun evli katılımcılarda bekâr katılımcılara oranla daha yüksek olduğu görülmektedir. Aynı şekilde ÇBASDÖ-aile destek evli katılımcılarda bekâr katılımcılara göre daha yüksek çıkmıştır. Bu bilgilerle birlikte hem iş doyumu hem algılanan sosyal destekte medeni duruma göre bir değişim olduğu sonucuna ulaşılmıştır. Araştırmadan elde edilen bulgular literatürle uyuşmaktadır. Yapılan birçok araştırma medeni durumun iş doyumu düzeyine etki ettiği sonucunu desteklemektedir. Dost ve Cenkseven ögretim elemanlarıyla yaptıkları çalışmada iş doyumunu sadece medeni durumun etkilediğini belirtmişlerdir. Bu araştırmanın sonucuyla benzer bir sonuca ulaşarak evli öğretim elemanlarının iş doyumlarının bekâr öğretim elemanlarından daha yüksek olduğu sonucuna ulaşmışlardır. 


\section{Merve BAŞ, Melisa AKSU, Hüseyin ÜNÜBOL ve Gökben HIZLI SAYAR}

Mesleki kıdemlere bakıldığında algılanan sosyal destek düzeyinde anlamlı bir farklılık bulunmazken iş doyumu düzeylerinde farklılık saptanmıştır. MIDÖ-genel doyum ve dışsal doyum 21 yıl ve üzeri görev yapanlarda daha yüksek çıkmıştır. Akademisyenlerin yürüttükleri lisansüstü tez sayısına göre ölçek puanlarına bakıldığında 5'ten daha fazla lisansüstü tezi yürüten katılımcılarda algılanan sosyal destek düzeyinde anlamlı bir farklılık bulunmuştur. ÇBASDÖ-diğer önemli kişi ve toplam puanları 5 'ten fazla lisansüstü tezi yürüten katılımcılarda daha yüksektir. Akman vd. öğretim elemanlarıyla yaptıkları araştırmada hizmet süresi açısından benzer bir sonuca ulaşmışlardır. Araştırmanın sonucuna göre hizmet süresi fazla olanların iş doyumunun daha fazla olduğunu belirtmişlerdir. ${ }^{5}$ Öztürk ve Şahbudak ise iş doyumu ve çalışma

Üsküdar University Journal of Social Sciences, 2019; issue: 9 , $347-377$ süresi arasında ilişki olduğunu gösteren araştırmaların çoğunlukta olduğunu belirterek bu araştırmalardan kimisinin hizmet süresi arttıkça iş doyumunun arttığını gösterdiğini, kimisinin ise hizmet süresi arttıkça iş doyumunun düştüğünü gösterdiğinden bahsetmişlerdir. ${ }^{6}$ Buradan da anlaşılabileceği üzere araştırmadan elde edilen bulgu literatürdeki bilgilerle uyuşmaktadır.

Araştırmanın sonucuna göre iş doyumunun yaş ve unvana göre anlamlı bir şekilde değişmediği sonucuna ulaşılmıştır. Literatürde benzer sonuçlara ulaşan araştırmalara rastlamak mümkündür. Dost ve Cenkseven araştırmalarında iş doyumunun yaş ve unvana göre farklılaşmadığı sonucuna ulaşmışlardır. ${ }^{19}$ Elde edilen bilgilerle birlikte hem iş doyumu hem algilanan sosyal destek düzeylerinin cinsiyet ve medeni duruma göre değiştiği bulunmuştur. Mesleki kıdeme göre iş doyumunda değişim olduğu ve yürütülen lisansüstü tez sayısına göre algılanan sosyal destek düzeyinde değişim olduğu görülürken; yaş, unvan, akademisyenlik durumu, ailede akademisyen olması ve haftalık ders saatine göre her iki ölçekten elde edilen puanlarda bir farklılık olmadığı sonucuna ulaşılmıştır.

\section{Sonuç}

Algılanan sosyal doyum ve destek ile birlikte, iş doyumu üzerinde pek çok araştırma yapılan önemli iki kavramdır. Yükseköğretim kurumları ise 
Akademisyenlerde İş Doyumunun Algılanan Sosyal Destekle İlişkisi

toplumların gelişebilmesi açısından önem taşımaktadır. Bu kurumların daha başarılı olabilmesi için en önemli rollerden biri de akademisyenlere düşmektedir. Bu araştırmada da akademisyenlerin iş doyumuyla algılanan sosyal destek düzeyleri arasındaki ilişkinin incelenmesi amaçlanmıştır. Araştırma, Üsküdar Üniversitesi akademisyenlerini kapsamaktadır ve araştırmanın örneklemini 84 akademisyen oluşturmaktadır. Araştırmadan elde edilen bilgilerle birlikte algılanan sosyal destek ve iş doyumunun birbiriyle ilişkisiz olduğunu söylemek mümkün olmayacaktır, çünkü araştırmada kullanılan ölçeklerin dışsal doyum ve diğer önemli kişi destek alt boyutları arasında bir ilişki olduğu sonucu ortaya çıkmıştır. Bu bilgilere ek olarak yaş, unvan, ailede akademisyen olma durumu ve haftalık ders saatinin, iş doyumu ve algılanan sosyal destek düzeylerinde bir değişikliğe sebep olmadığı sonucuna ulaşılırken, hem cinsiyet hem medeni durumun iş doyumu ve algılanan sosyal destek düzeyleri üzerinde etkili olduğu sonucuna ulaşılmıştır.

\section{Öneriler}

Akademisyenlerin toplumdaki önemi ve yeri tartışlamaz. $\mathrm{Bu}$ nedenle akademisyenlerin mesleklerine olan bağlılığı ve mesleklerini severek yapmalarının topluma olumlu katkıları olacaktır. Her bireyin kişilik özelliklerinin, karakterinin farklı olması dolayısıyla, her bireyin iş doyumuna etki edebilecek faktörler farklılık gösterebilir. Ancak örgütler içerisinde bazı değişkenlerin çalışanların iş doyumu üzerinde etkili olduğu bilinmektedir. $\mathrm{Bu}$ araştırmada iş doyumu ve algılanan sosyal destek arasında kısmen ilişki bulunmuştur. Bu konuda pek fazla araştırmanın olmaması sebebiyle bu araştırmanın farklı üniversitelerde ve daha geniş örneklemler kullanılarak yapılması önerilir.

Akademisyenlerde iş doyumunu artırmak için gerekli önlemlerin alınması noktasında sadece ücret ve fiziksel koşullar değil, duygusal ve sosyal etmenlerin de önemli olduğu unutulmamalıdır. İş doyumunun belirli aralıklarla takip edilmesi, iş doyumu düşük olan gruplarda sosyal desteği artıracak iyileştirmelerin yapılması önerilir. 


\section{Merve BAŞ, Melisa AKSU, Hüseyin ÜNÜBOL ve Gökben HIZLI SAYAR}

\section{KAYNAKÇA}

Akman, Yasemin, Filiz Bilge ve Hülya Kelecioğlu. "Öğretim Elemanlarının İş Doyumlarının İncelenmesi.” Hacettepe Üniversitesi Eğitim Fakültesi Dergisi, say1: 32 (2007): 32-41.

Alderfer, Clayton P.. Existence, Relatedness and Growth. New York: Free Press, 1972.

Aliyev, Ramin ve Erhan Tunç. "Ortaokul Öğrencilerinin Algılanan Sosyal Destek Düzeyi ve Benlik Algılarının İncelenmesi.” Atatürk Üniversitesi Sosyal Bilimler Enstitüsü Dergisi 2, sayı: 21 (2017): 401-418.

Ardahan, Melek. "Sosyal Destek ve Hemşirelik." Atatürk Üniversitesi

Üsküdar University Journal of Social Sciences, 2019; issue: 9 , $347-377$

Hemşirelik Yüksekokulu Dergisi 2, sayı: 9 (2006): 68-75.

Aşık, Nuran A.. "Çalışanlarda İş Doyumunu Etkileyen Bireysel ve Örgütsel Faktörler ile Sonuçlarına İlişkin Kavramsal Bir Değerlendirme.” Türk İdare Dergisi, say1: 467 (2010): 31-51.

Bayraktar, Özlem. "Üniversite Öğrencilerinin Algılanan Sosyal Destek Düzeyleri ile Duygusal Zekâları Arasındaki İlişkinin İncelenmesi.” Yayımlanmamış Yüksel Lisans Tezi, Selçuk Üniversitesi Eğitim Bilimleri Enstitüsü, Konya, 2011.

Bano, Safia, Saubia Ramzan, Muhammad Adeel Anjum ve Lian Dapeng. "Does Perceived Social Support Mediate The Relationship of Perceived Organizational Support and Job Satisfaction? A Structural Equation Modeling Approach.” Journal of Managerial Sciences 3, say1: 11 (2017): 105-118.

Brough, Paula ve Judi Pears. "Evaluating The Influence of The Type of Social Support on Job Satisfaction and Work Related Psychological WellBeing." International Journal of Organizational Behaviour 2, sayı: 8 (2004): 472-485. 
Akademisyenlerde İ̧ Doyumunun Algılanan Sosyal Destekle İlişkisi

Cenkseven, Fulya ve Meliha Tuzgöl Dost. "Öğretim Elemanlarının Sosyodemografik Değişkenlere ve Üniversitelerini Değerlendirmelerine Göre İş Doyumları.” Eğitim ve Bilim 148, sayı: 33 (2008): 28-39.

Clark, Andrew, Andrew Oswald ve Peter Warr. "Is Job Satisfaction U-Shaped in Age?" Journal of Occupational and Organizational Psychology, say1: 69 (1996): 57-81.

Cohen, Sheldon ve Thomas A. Wills. "Stress, Social Support and Buffering Hypothesis.” Psychological Bulletin 2 say1:98 (1995): 310-357.

Dikmen, Ahmet A. "İş Doyumu ve Yaşam Doyumu İlişkisi." Ankara Üniversitesi SBF Dergisi, say1:50 (1995): 115-140.

Dugguh, Stephen ve Ayaga Dennis. "Job Satisfaction Theories: Traceability to Employee Performance in Organizations." Journal of Business and Management 5, say1:16 (2014): 11-18.

Ergeneli, Azize ve Mehmet Eryiğit. "Öğretim Elemanlarının İş Tatmini: Ankara'da Devlet ve Özel Üniversite Karşılaştırması.” H. Ü. İktisadi ve İdari Bilimler Fakültesi Dergisi 2, sayı:19 (2001): 159-178.

Hotamışlı, Mustafa ve Veysel Ağca. "Öğretim Elemanları İş Tatmin Düzeylerinin Demografik Özelliklere Göre Değişmesi: Türkiye’de Kamu ve Vakıf Üniversitelerinde Karşılaştırmalı Bir Araştırma." Sosyal Bilimler Dergisi 2, say1:12 (2010): 95-118.

House, James S., Karl R. Landis ve Debra Umberson. "Social Relationships and Health.” Science 4865 sayı: 241 (1988): 540-545.

Karlıdağ, Rıfat, Süheyla Ünal ve Salim Yoloğlu. "Hekimlerde Tükenmişlik ve İş Doyumu Düzeylerinin Yaşam Doyumu Düzeyleri ile İlişkisi.” Klinik Psikiyatri, say1: 4 (2001): 113-118.

Kırel, Çiğdem. "Esnek Çalışma Saatleri Uygulamalarında Cinsiyet, İş Tatmini ve İş Bağlılığı İlişkisi.” İ. Ü. İşletme Fakültesi Dergisi 2, sayı: 28 (1999): 115-136. 


\section{Merve BAŞ, Melisa AKSU, Hüseyin ÜNÜBOL ve Gökben HIZLI SAYAR}

Krishna, Siva Rama ve Raja Nandan. "Determinants of Job Satisfaction of Faculty in Higher Education." The Indian Journal of Industrial Relations 1, say1: 49 (2013): 132-147.

Küçüközkan, Yasemin. "Liderlik ve Motivasyon Teorileri: Kuramsal Bir Çerçeve.” Uluslararası Akademik Yönetim Bilimleri Dergisi 2 sayı: 1 (2015): 86-115.

Mowday, Richard T., Debra L. Shapiro ve Richard M. Steers. "Introduction to Special Topic Forum: The Future of Work Motivation Theory." Academy of Management Review 3, say1: 29 (204): 379-387.

Temel Eğinli, Ayşen. "Çalışanlarda İş Doyumu: Kamu ve Özel Sektör

Üsküdar University Journal of Social Sciences, 2019; issue: 9 , $347-377$

Çalışanlarının İş Doyumuna Yönelik Bir Araştırma." Atatürk Üniversitesi İktisadi ve İdari Bilimler Dergisi 3 sayı: 23 (2009): 35-52.

Onaran, Oğuz. Çalışma Yaşamında Güdülenme Kuramları. Ankara: Ankara Üniversitesi Siyasal Bilgiler Fakültesi Yayınları, 1985.

Özaydın, Mehmet Merve ve Ömer Özdemir. "Çalışanların Bireysel Özelliklerinin İş Tatmini Üzerindeki Etkileri: Bir Kamu Bankası Örneği.” İşletme Araştırmaları Dergisi 1, sayı: 6 (2014): 251-281.

Öztürk, Meral ve Ercan Şahbudak. "Akademisyenlikte İş Doyumu." Uluslararası Sosyal Araştırma Dergisi 40, sayı: 8 (2015): 494-501.

Singh, Ashak P., Amish Singh ve Nitu Singhi. "Organizational Role Stress and Social Support as Predictors of Job Satisfaction Among Managerial Personnel." Journal of Psychosocial Research 1, say1: 10 (2015): 1-10.

Sun, Özlem. "İş Doyumu Üzerine Bir Araştırma: Türkiye Cumhuriyeti Merkez Bankası Banknot Matbaası Genel Müdürlüğü." Uzman Yeterlilik Tezi, Ankara: TCMB Banknot Matbaası Genel Müdürlüğü, 2002. 
Akademisyenlerde İş Doyumunun Algılanan Sosyal Destekle İlişkisi

Weiss, David J., Rene V. Dawis, George W. England ve Lloyd H. Lofquist. Manual for the Minnesota Satisfaction Questionnaire. Minneapolis: University of Minnesota, Industrial Relations Center, 1967.

Vangelesti, Anita L.. "Challenges in Conceptualizing Social Support." Journal of Social and Personal Relationships 1, say1: 26 (2009): 39-51.

Vroom,Victor H.. Work and Motivation. New York: Wiley, 1964.

Zimet, Gregory D.. "The Multidimensional Scale of Perceived Social Support." Journal of Personality Assessment 1, say1: 52 (1998): 30-41.

Üsküdar Üniversitesi Sosyal Bilimler Dergisi, 2019; sayl: 9 , $347-377$ 
